\title{
NINE-YEAR RECORD OF ALNUS POLLEN DEPOSITION IN THE ROZTOCZE REGION (SE POLAND) WITH RELATION TO VEGETATION DATA
}

\author{
Irena Agnieszka Pidek
}

\author{
Institute of Earth Sciences, Maria Curia-Skłodowska, University in Lublin, Al. Kraśnicka 2 c/d, 20-718 Lublin, Poland \\ e-mail: ipidek@biotop.umcs.lublin.pl
}

Received: 02.10.2007

\section{S u m m a r y}

Pollen deposition of alder has been measured at ground level by means of nine modified Tauber traps in different plant communities according to rules of the Pollen Monitoring Programme (http://pmp.oulu.fi). The series of data covers the period 1998-2006. The area under investigation is situated in the Roztocze (surroundings of the Guciów village) within the protective zone of the Roztocze National Park. During nine years of monitoring, significant variations were observed between single years of deposition. The occurrence of peak years $(1998,2001,2003$ and 2006) connected with higher production of Alnus pollen was observed at many pollen monitoring sites, but its relationship with different proportions of alder within the surrounding vegetation seems rather weak. The average value of annual pollen deposition of Alnus for the whole region was calculated at ca. 1370 grains . $\mathrm{cm}^{-2}$. At the sites situated within the open landscape, pollen influx values ranged from 442 (in 2005) to 6894 (in 1998). It seems that other factors than the proportion of alder within the vegetation control the deposition of Alnus pollen. Long-distance transport and meteorological factors such as wind speed and direction should be taken into account in future studies.

Key words: pollen monitoring, Alnus pollen, modern pollen deposition, pollen-vegetation relationship, Tauber traps

\section{INTRODUCTION}

In Poland three species of Alnus Mill. genus occur, from among which the most widespread is common alder Alnus glutinosa /L./ Gaertn. ( $\mathrm{Z}$ a j ą c and $\mathrm{Z}$ a j ą c , 2001). As an anemophilous tree belonging to the Betulaceae family, common alder produces a great amount of pollen triggering allergic reactions. For that reason, it arouses interest of aerobiologists and allergists. In our country Alnus pollen appears in the air very early, often in the first decade of February (K a s przy k et al. 2004; S zczepanek, 2006; S m ith et al. 2007; Weryszko-Chmielewska and Piotrow- s k a, 2004; 2006). Due to cross reactivity of alder and birch pollen, not only the concentration of Alnus pollen has been analysed, but also the course of pollen seasons and related meteorological factors $(\mathrm{G}$ i o u l e k a s et al. 2004; K a s p rzy k et al. 2004; R o drig u e z - R a j o et al. 2006; S m it h et al. 2007). Pollen seasons of early spring flowering taxa, such as Alnus and Corylus, are quite sensitive to the increase in global air temperature. Thus, these taxa are important in the context of global climate change (E m berlin et al. 2007; R od rig u e $\mathrm{z}-\mathrm{R}$ ajo et al. 2004). There is also a palaeoecological aspect of the studies on alder pollen. Analysis of its deposition at the ground level, in situations analogous to deposition in mid-forest mires in the past, can shed light on the problem of the Holocene expansion of alder. Isopollen maps indicate that it occurred in two stages. The first stage, about $8500 \mathrm{C}^{14}$ years BP, is related to the migration of Alnus incana along the Vistula River valley. Alnus glutinosa was probably responsible for the second expansion wave about $8000 \mathrm{C}^{14}$ years BP (S z c z e panek et al. 2004). Quantifying the relationship between pollen deposition of Alnus and the occurrence of this tree within the vegetation at known distances from a pollen-trapping site can help to solve palaeoecological problems concerning alder communities which are reflected by fossil pollen diagrams. Such studies, based on the rules of the Pollen Monitoring Programme, have been conducted in the Middle Roztocze region since 1998 . The project aims at studying pollen dispersal and deposition of different tree, shrub, and herb taxa by means of Tauber traps in the conditions as natural as possible. Diverse natural biotopes of the Roztocze, which is cut by the Wieprz River valley, caused the formation of about 20 forest associations, among which also Ribeso nigri-Alnetum association occurs together with initial forms of alder riverside carrs (Fraxino-Alnetum) growing along the Wieprz River channel (I z d e b s k i et al. 1992). 
The purpose of this paper is to analyse the nine-year series (1998-2006) of data concerning alder pollen deposition, and to relate these data to the proportion of alder in vegetation communities surrounding pollen traps. Such analysis can help to find a solution to a problem to what extent the deposited alder pollen represents local vegetation. This question is essential not only for palaeoecological interpretations, but it can also shed light on the problem of long-distance transport of alder pollen, which is important for allergy sufferers.

\section{MATERIALS AND METHODS}

\section{Monitoring pollen deposition}

Monitoring of Alnus pollen deposition has been conducted by means of nine Tauber traps (T a u ber, 1974; Hicks and Hyvärinen, 1986) in the years 1998-2006 in frame of the Pollen Monitoring Programme (PMP). Pollen gathered during the whole calendar year was subjected to laboratory treatment with the use of Lycopodium tablets (S t o c k m a r r, 1971) followed by microscopic analysis (H i c k s et al. 1996). The PMP method makes it possible to count pollen influx values (PI), i.e. number of pollen grains of a given taxon per 1 $\mathrm{cm}^{2}$ a year. Detailed guidelines to the PMP method published by Hicks and co-authors $(1996 ; 1999)$ can be found also at http://pmp.oulu.fi.

In the Roztocze plastic containers were used as modified Tauber traps. Opening of $5 \mathrm{~cm}$ in diameter was covered by a wire net with large meshes (vide $\mathrm{P} \mathrm{i} \mathrm{d} \mathrm{e} \mathrm{k}$, 2004). Five Lycopodium tablets were added to the trap contents, followed by filtering and standard acetolysis. Microscopic analysis was continued until minimum 500 tree and shrub pollen grains (AP) were counted and minimum 100 Lycopodium spores were encountered. Pollen influx values were calculated separately for each taxon-Alnus among others.

The calculated annual alder pollen sums per $1 \mathrm{~cm}^{2}$ (pollen influx values) are presented in Table 2. The table contains pollen influx values for 9 pollen traps in the period 1998-2006. The PI values higher than average ones for at least $30 \%$ for a particular site are considered high values and marked in bold. Due to damage of a pollen trap during vegetation season, several data are lacking which have been marked by a horizontal line.

\section{Area under investigation}

The area under investigation is situated in the Middle Roztocze region in the surroundings of the Guciów village. The region of the Roztocze forms a belt of elevations in south-eastern Poland, on the border between Poland and Ukraine (Fig.1) and differs from neighbouring regions by its geologic structure, surface relief, climate, waters, soils and vegetation cover $(\mathrm{Bu}-$ raczyński, 2002).

The characteristic feature of the Roztocze region is an extensive forest cover and low degree of anthropogenic changes of landscape due to moderate agrarian activity (J a n i cki and Woj tan ow ic z, 1997). About $60 \%$ of the Roztocze forests are of natural or semi-natural origin up till now. They can be divided into, among others, coniferous forests, dry-ground forests, alder woods and riverine forests. These communities were classified into 18 associations and two communities (Izdebski , 2002). The forests of the Middle Roztocze are the most precious. They are protected within the Roztocze National Park, founded in 1974. The area under investigation is situated within the protected zone of the Park (Fig. 2).

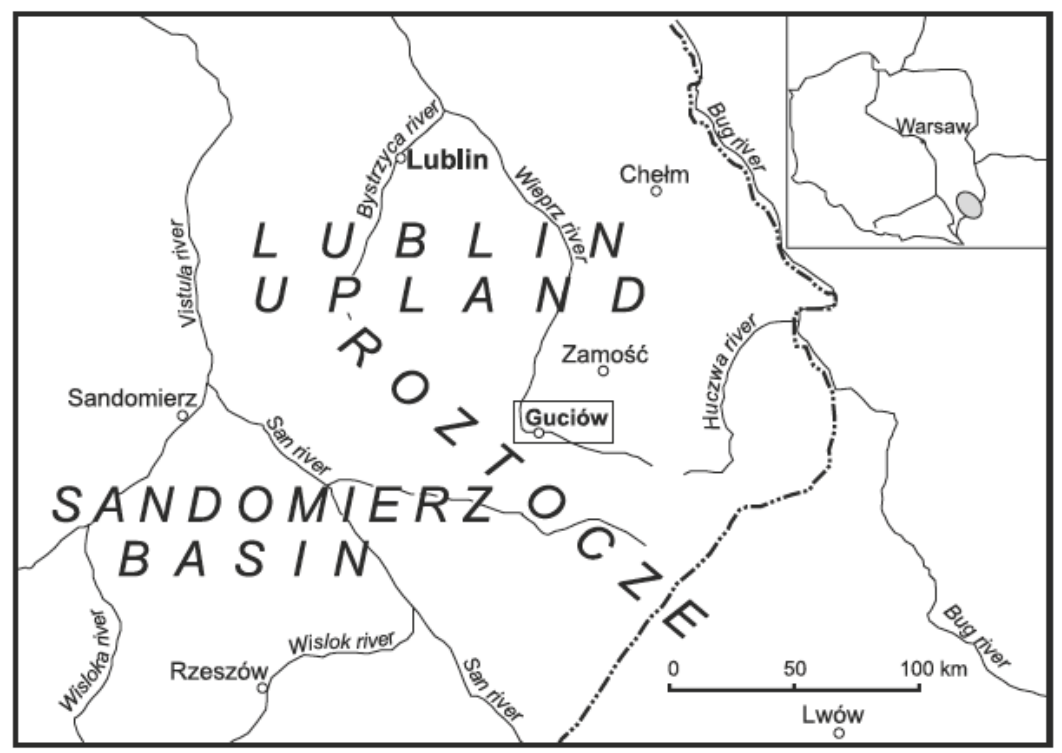

Fig. 1. Location of the area under investigation. 


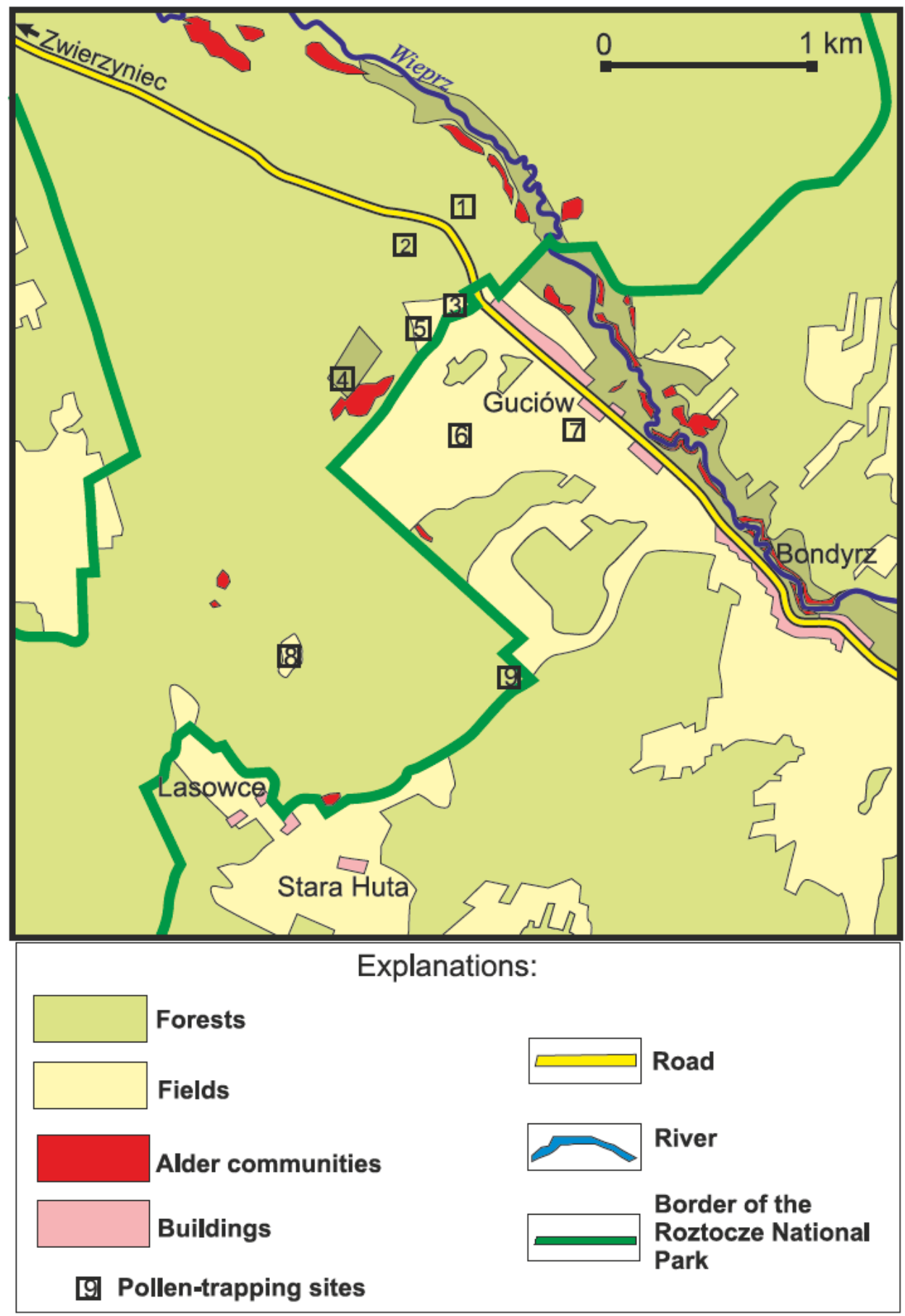

Fig. 2. Pollen-trapping sites in the area under investigation on the background of alder communities.

Alnus glutinosa is the only species of alder occurring in the study area (Izdebski et al. 1992). According to Bałaga (1998), the formation of alder communities in the Roztocze started at ca. $8330 \pm 150 \mathrm{C}^{14}$ years BP. This date seems a little earlier than the one considered by Szczepanek and co-authors (2004). Alder communities in the Roztocze grow mainly on peaty soils along the Wieprz River channel as well as in wet hollows without outflow. In the surroundings of the Gu- ciów village, patches of Ribeso nigri-Alnetum association as well as riverine alder carrs of Fraxino-Alnetum association occur along the lower terrace of the river. They occupy ca. 4 ha in total within the Guciów village itself ( $\mathrm{Gradziel}$ et al. 2006). The nomenclature of the associations followed M a t u s zk i e w i c z (2001).

Figure 2 illustrates the situation of pollen traps on the background of areas overgrown by various alder tree-stands. This map was based on the detailed 
maps of forest communities of the Roztocze National Park (I z d e b s k i et al. 1992) as well as on the maps of plant communities of the Guciów village ( $\mathrm{Gr}$ a d z i e 1 and Janicki, 2002; Graqziel et al. 2006). Air photos and author's field observations were used, too. Due to the scale of the map, single alder trees along the Wieprz River and in the vicinity of the trap no. 2 were not marked.

\section{RESULTS} nities

Situation of pollen traps against alder commu-

The distance between the pollen trap and the nearest flowering Alnus trees differs very significantly at individual sites. Alder trees appear the closest to the trap $(40 \mathrm{~m})$ at the site 2 (to SE and NE directions from the pollen trap). They grow along the forest edge, in wet meadow. A patch of alder carr of Ribeso nigri-Alnetum association occurs also very close (100m) to the trap 4 (Fig. 2). The distances at other pollen-trapping sites are much greater. Table 1 contains a brief description of the sites and the approximate distance from the nearest alder trees.

The two sites (6 and 7) are intended to be "regional" ones to gather not only local but also regional pollen rain coming from outside the local vegetation. They were situated in open landscape within cultivated and abandoned fields.

\section{Pollen data}

Pollen deposition of Alnus differed very significantly in individual years and between the sites. The differences between the sites were much smaller than between PI values in different years at the same site. The years of high pollen deposition (1998, 2001, 2003 and 2006) were observed, as well as the years of very low

Table 1

Description of pollen-trapping sites in the area under investigation.

\begin{tabular}{|c|l|l|}
\hline $\begin{array}{c}\text { Site } \\
\text { No }\end{array}$ & \multicolumn{1}{|c|}{ Site description } & \multicolumn{1}{c|}{ Distance from the nearest alder trees } \\
\hline 1 & Small opening within fir forest & $250 \mathrm{~m}$ - alder communities in the river valley \\
\hline 2 & $\begin{array}{l}\text { Big, wet meadow within mixed } \\
\text { forest }\end{array}$ & $\begin{array}{l}40 \mathrm{~m} \text { - single alder trees and } 650 \mathrm{~m} \text { - alder communities } \\
\text { in the river valley }\end{array}$ \\
\hline 3 & Mixed forest edge & $550 \mathrm{~m}$ - alder communities in the river valley \\
\hline 4 & Big opening within mixed forest & $100 \mathrm{~m}$ - patch of alder carr \\
\hline 5 & Forest edge of beech wood & $300 \mathrm{~m}$ - alder carr at the site 4 \\
\hline 6 & $\begin{array}{l}\text { Open landscape (cultivated } \\
\text { and abandoned fields) }\end{array}$ & $\begin{array}{l}400 \mathrm{~m} \text { - alder carr at the site } 4 \text { and } 700 \mathrm{~m} \text { - alder communities } \\
\text { in the river valley }\end{array}$ \\
\hline 7 & $\begin{array}{l}\text { Open landscape (cultivated } \\
\text { and abandoned fields) }\end{array}$ & $200 \mathrm{~m}$ - alder communities in the river valley \\
\hline 8 & Big opening within beech wood & $500 \mathrm{~m}$ - patch of alder carr to the western side \\
\hline 9 & $\begin{array}{l}\text { Very small opening within } \\
\text { beech wood }\end{array}$ & $\begin{array}{l}900 \mathrm{~m} \text { - patch of alder carr to the western side and } 1500 \mathrm{~m} \\
- \text { alder communities in the river valley }\end{array}$ \\
\hline
\end{tabular}

(1999, 2000 and 2005) and average deposition (2002 and 2004). Pollen influx values for alder calculated for all nine trapping sites in the years 1998-2006 are presented in Table 2.

The average value of annual alder pollen deposition for the study area was calculated at 1368 grains $\times \mathrm{cm}^{-2}$. It was based on all the results from the pollen-trapping sites during nine years of monitoring. This value is more accurate than the first rough estimates (1419 Alnus pollen grains $\times \mathrm{cm}^{-2}$ annually) based on four years' data (P i d e k, 2004). In the peak years, the PI values significantly surpassed the average deposition. In 1998 the highest among average values was recorded, i.e. over 4300 Alnus pollen grains $\times \mathrm{cm}^{-2}$ (Fig. 3). However, taking into account that only three traps survived the first season of pollen monitoring, the result should be treated with limited confidence. In 2000 the lowest average value (365) of pollen deposition was recorded. In this case, the two regional traps were damaged which could influence the PI values quite significantly.

Taking into account the average values of Alnus pollen deposition at each of the monitoring sites (Tab. 2), the highest PI was recorded at the sites 6 and 4 situated quite close to the patch of alder carr. The alder trees 
Table 2

Pollen influx values for 9 traps in the period 1998-2006. Values higher than average for at least $30 \%$ are marked in bold. Horizontal line means lack of data.

\begin{tabular}{|c|c|c|c|c|c|c|c|c|c|c|}
\hline Site no & 1998 & 1999 & 2000 & 2001 & 2002 & 2003 & 2004 & 2005 & 2006 & average \\
\hline 1 & -- & 362 & 173 & $\mathbf{9 8 8}$ & -- & $\mathbf{6 4 8}$ & 512 & 319 & -- & 500 \\
\hline 2 & -- & 483 & 363 & $\mathbf{1 3 3 4}$ & 1079 & $\mathbf{1 1 3 7}$ & $\mathbf{1 3 6 2}$ & 392 & 424 & 822 \\
\hline 3 & $\mathbf{2 2 9 4}$ & 863 & 712 & $\mathbf{1 4 4 0}$ & 1040 & $\mathbf{1 7 1 2}$ & 1167 & 544 & $\mathbf{2 0 0 4}$ & 1308 \\
\hline 4 & $\mathbf{3 8 5 4}$ & 675 & 209 & $\mathbf{3 4 0 5}$ & 1094 & $\mathbf{2 2 6 1}$ & 1043 & -- & $\mathbf{2 0 4 9}$ & 1824 \\
\hline 5 & -- & 603 & 106 & $\mathbf{2 2 1 1}$ & 916 & $\mathbf{2 7 7 6}$ & 681 & 290 & $\mathbf{1 8 8 2}$ & 1183 \\
\hline 6 & $\mathbf{6 8 9 4}$ & 675 & -- & $\mathbf{3 1 8 9}$ & 1274 & $\mathbf{3 1 5 1}$ & 1199 & 389 & $\mathbf{3 2 7 7}$ & 2506 \\
\hline 7 & -- & 706 & -- & $\mathbf{1 9 1 5}$ & 1337 & $\mathbf{1 8 7 6}$ & 628 & 442 & $\mathbf{2 8 7 5}$ & 1397 \\
\hline 8 & -- & 589 & 240 & -- & 1283 & $\mathbf{7 7 1}$ & 1335 & 873 & $\mathbf{2 1 5 7}$ & 1035 \\
\hline 9 & -- & 1222 & $\mathbf{7 5 5}$ & $\mathbf{2 0 5 5}$ & 1607 & -- & 735 & -- & $\mathbf{4 0 4 9}$ & 1737 \\
\hline
\end{tabular}

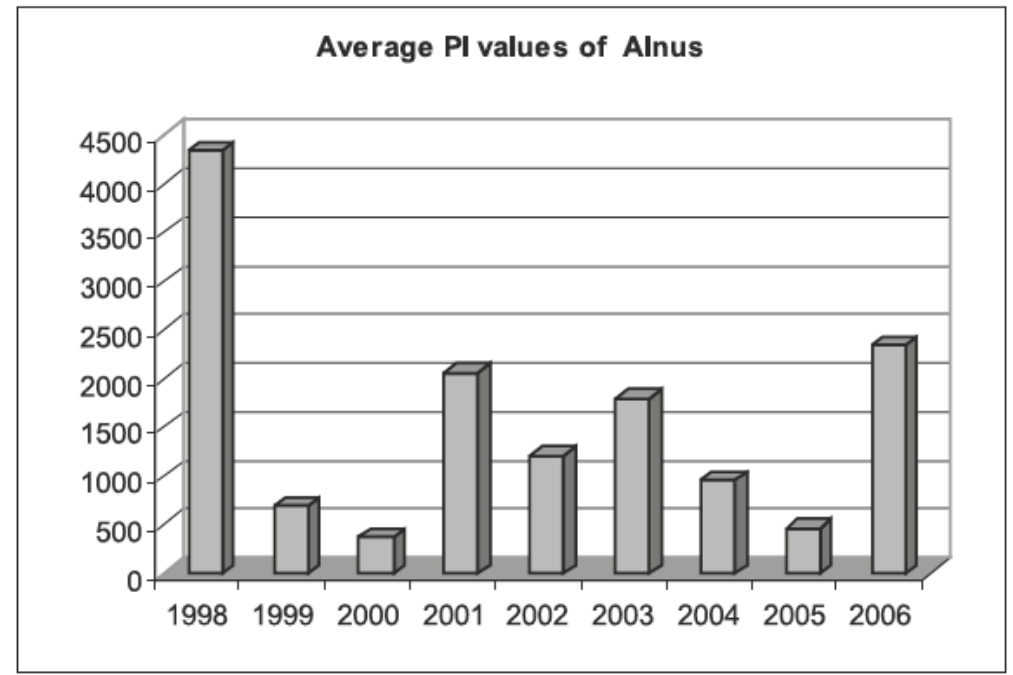

Fig. 3. Average pollen influx values for the period 1998-2006.

were at a distance of $100 \mathrm{~m}$ from the trap 4 and ca. 400 $\mathrm{m}$ from the trap 6 . The third, in terms of average annual deposition, was the site no. 9 which, on the opposite, was situated far away from the nearest alder trees, i.e. $900 \mathrm{~m}$ (Fig. 2).

Considering the data obtained in the years of abundant Almus pollen deposition (1998, 2001, 2003 and 2006), it should be stressed that, as a rule, very high PI values were observed at the same site, i.e. 6, frequently also at the site 4 and sporadically at the sites 5 and 7 . The lowest values were recorded at the sites 1 and 2, but sporadically also at the sites 3 and 8 .
However, deposition during the low years showed another pattern, and the highest values were calculated for the sites 9 and 3 , sporadically also for the site 8 .

The years 2002 and 2004 were considered average in terms of Alnus pollen deposition, but in 2004 the values at several sites were higher than in 2002. For example, at the sites 2 and 8 they surpassed the average values for the nine years period (Tab. 2). In 2002 the highest were the values at the site 9 (1607), while at most of the sites $(2,3,4,5,6,7$ and 8) they ranged from 900 to 1300 , i.e. 916 (site 5), 1040-1094 (sites 2, 3 and 4), 1274-1337 (sites 6, 7, and 8). 


\section{DISCUSSION}

Considerable differences in the values of Alnus pollen deposition in particular years are not surprising in the present investigations in the Roztocze region. They undoubtedly result from the diverse pollen production conditioned by many factors. Several years' monitoring of pollen deposition in Cracow by means of gravimetric method indicated that annual pollen sums of Alnus fluctuated between 359 and 1749 (Szczepanek, 2006). Peak and low years were recorded also in two cities, i.e. Lublin and Rzeszów, located in the regions adjoining the Roztocze from the north and the south, in which aerobiologic monitoring was conducted by means of volumetric method. The comparison of annual pollen sums recorded in Lublin, Rzeszów and in the Roztocze reveals rather great conformity in the occurrence of years with high and low pollen production of this taxon $(\mathrm{K} \mathrm{a}-$ sprzyk, 2006; Pidek et al. 2006; Weryszko- Chmielewska and Piotrowska, 2006).

Although as a rule the peak years were followed by low or average-deposition ones in the Roztocze, it should be stressed that biannual rhythm of abundant deposition of alder pollen did not unambiguously appear in the analysed period (1998-2006). Its occurrence was discussed among others by Spanish aerobiologists ( $\mathrm{R}$ o d rig u e z - R a j o et al. 2004) who suggested that some taxa flowering in winter, such as alder, reveal approximately biannual rhythm of abundant pollen production, though sometimes a year of abundant production of $\mathrm{Al}$ nus pollen is preceded by two years of low production (A ir a et al. 1998).

Analysis of pollen influx in particular sites indicated that the deposition of alder pollen reached the highest values several times at the sites 4 and 6 (mostly during the peak years) and at the sites 3 and 9 (mostly during the low years). The first site is situated close to the association of Ribeso nigri-Alnetum, i.e. at a distance of $100 \mathrm{~m}$. Therefore, in this case the proximity of alder carr might be the main factor influencing the PI. At the sites 3, 6 and 9 (situated at a distance of 400-900m from the alder communities), we should search for other explanation of high PI values. Sporadically, the highest PI values occurred also at the sites 5, 7 and 8 where the distance from the nearest Alnus communities ranged from 200 to $500 \mathrm{~m}$.

Surprisingly, only twice the highest PI was recorded at the site 2 where the nearest alder trees grow very close to the trap $(40 \mathrm{~m})$.

Thus, the relationship between the value of Alnus pollen deposition and the proportion of alder in vegetation communities surrounding the pollen trap seems to be rather weak. Alder pollen influx probably represents local trees to a low degree, and it depends largely on regional vegetation. Alnus pollen comes mostly from large patches of alder communities growing in the
Wieprz River valley. It seems that transport from the valley environs can be the most important factor controlling the spread of alder pollen. This can be favoured by strong winds occurring mostly in colder seasons of the year (K a s z e w s k i et al. 2002). Pollen grains must be transported upslope, as the sites 6, 8, and 9 occur in the highest positions over the valley, i.e. several dozen metres above the upper terrace of the Wieprz River. Both the surrounding vegetation and the distance from alder communities are different in the case of each mentioned site.

Landscape openness certainly favours the spread of pollen. Such situation occurs in the instance of the sites 6 and 7, though pollen reaching the site 7 has to clear a small obstacle of a pine-birch tree patch. However, even the occurrence of beech forest in close (several metres) or more distant $(100 \mathrm{~m})$ vicinity of the trap does not seem to be a significant obstacle for penetration of alder pollen. In the period of alder flowering, beech trees are still leafless, so winds of different directions can transport masses of alder pollen to different places. That is why the highest values of PI were recorded in particular years at different sites. The lowest values are usually found in the site 1 that is situated not far from the alder communities, but in a small clearing within dense fir forest which can stop most of penetrating alder pollen. Probably for the same reason, very low deposition was observed at the site 2 in the years 1999, 2001, 2002 and 2006. The importance of long-distance transport concerning plants flowering early in spring was also confirmed by observations from different regions in Poland $(\mathrm{K}$ a s przyk et al. 2004) as well as from other countries where alder pollen was found over $200 \mathrm{~km}$ away from its source area ( $\mathrm{S} \mathrm{u} \mathrm{s} \mathrm{z} \mathrm{k} \mathrm{a,} \mathrm{1980).}$

Pollen grain of alder is much smaller than the grains of coniferous trees, and the difference in fall speed is also considerable. The comparison of pollen productivity estimates after B ros trö m (2002) for Alnus (4.2), Betula (8.9), and Pinus (5.7) shows that alder trees are almost as efficient producers of pollen as pine trees. These values were used in modelling of source areas of pollen (S u git a et al. 1999) and stand in agreement with Andersen's (1970) investigations in Danish forests. The comparison of fall speeds of pollen grains of these three taxa (E i s e n h u t, 1961), which are for alder -0.021 , birch -0.024 , and pine -0.031 , also shows that alder pollen can be long-distance transported. These distances can be comparable to those at which pine and birch pollen is transported on a large scale. The preliminary estimation of a source area of pine pollen in the Roztocze region indicates that a considerable amount of pollen comes from the areas over $30 \mathrm{~km}$ away from pollen traps (P o s k a and P i e k, 2007). Therefore, it is not surprising that the highest values of alder pollen deposition are recorded not always in the same traps, and 
not always in traps situated closest to alder trees. Such incidental factors as wind direction, air currents, and precipitation have stronger influence on alder pollen deposition. Analysis of meteorological factors influencing Alnus pollen production and dispersal can shed light on the solution of this particular problem.

Acknowledgements: This research has been supported financially by the project

No N304 $09232 / 3590$ of the Ministry of Science and Higher Education in Poland (years 2007-2010).

\section{REFERENCES}

Aira M. J., Jato M.V., Iglesias M. I., 1998. Alnus and Betula pollen content in the atmosphere of Santiago de Compostella, North-West Spain (1993-1995). Aerobiologia, 14: 135-140.

Andersen S. T., 1970. The relative pollen productivity and pollen representation of north European trees, and correction factors for tree pollen spectra. Danmarks Geologiske Undersøgelse, II. Roekke, 96: 1-96.

Bałaga K., 1998. Post-Glacial vegetational changes in the Middle Roztocze (E Poland). Acta Palaeobot. 38, 1: 175-192.

Broström A., 2002. Estimating source area of pollen and pollen productivity in the cultural landscapes of southern Sweden - developing a palynological tool for quantifying past plant cover. LUNDQUA Thesis 46. Lund University.

Buraczyński J. (red.), 2002. Roztocze. Środowisko przyrodnicze. Wydawnictwo Lubelskie, Lublin.

Eisenhut G., 1961. Untersuchungen über die Morphologie und Ökologie der Pollenkörner heimischer und fremländischer Waldbäume (translated into English by Jackson S.T. and Juamann P. 1989). Hamburg, Paul Parey.

Emberlin J., Smith M., Close R., Adams-Groom B., 2007. Changes in the pollen season of the early flowering trees Alnus spp. and Corylus spp. in Worcester, United Kongdom, 1996-2005. J. Biometeorol. 51: 181-191.

Gioulekas D., Balafoutis Ch., Damialis A., Papakosta D., Giolekas G., Patakas D., 2004. Fifteen years' record of airborne allergenic pollen and meteorological parameters in Thessaloniki, Greece. J. Biometeorol. 48: 128-136.

Grądziel T., Janicki G., 2002. Studies on the vegetation in the area of the Guciów village (Central Roztocze). [In:] Volume of Abstracts. Pollen Monitoring Programme - 4th International Meeting, Lublin-Guciów, 25-30 September 2002. Dept. of Physical Geography and Palaeogeography, UMCS, Lublin: 32-33.

Grądziel T., Janicki G., Furtak T., Pidek I. A., Rodzik J., 2006. Ocena stopnia naturalności i kierunków przekształceń roślinności w oparciu o metody: fitosocjologiczną i krajobrazową (na przykładzie wsi Guciów na Roztoczu Środkowym). / Estimation of the naturality degree and transformation directions of the vegetation based on phytosociological and landscape methods (an example from the village of Guciów - Central Roztocze). Regionalne Studia Ekologiczno-Krajobrazo- we. Problemy Ekologii Krajobrazu, 15, Polska Asocjacja Ekologii Krajobrazu, Warszawa, part I: 401-412.

Hicks S., Hyvärinen V.-P., 1986. Sampling modern pollen deposition by means of 'Tauber traps': some considerations. Pollen et Spores 28: 219-242.

Hicks S., Ammann B., Latalowa M., Pardoe H., Tinsley H., 1996. European Pollen Monitoring Programme. Project Description and Guidelines. Oulu Univ. Press, Oulu, Finland.

Hicks S., Tinsley H., Pardoe H., Cundill P., 1999. European Pollen Monitoring Programme. Supplement to the Guidelines. Oulu Univ. Press, Oulu, Finland.

Izdebski K., 2002. Szata roślinna i jej ochrona. / Vegetation cover and its protection. [in:] Buraczyński J. (red.) Roztocze. Środowisko przyrodnicze. / Roztocze. Natural Environment. Wyd. Lubelskie, Lublin: 272-321.

Izdebski K., Czarnecka B., Grądziel T., Lorens B., Popiołek Z., 1992. Zbiorowiska roślinne Roztoczańskiego Parku Narodowego na tle warunków siedliskowych (Plant communities against the background of the Roztocze National Park habitat conditions). Wyd. UMCS, Lublin.

Janicki G., Wojtanowicz J., 1997. Przeobrażenia antropogeniczne środowiska przyrodniczego Roztocza / Anthropogenic changes of the Roztocze natural environment. Ann. UMCS, sect. B, 42, Lublin: 147-158.

Kasprzyk I., 2006. Pyłek wybranych taksonów roślin w powietrzu Rzeszowa, 2001-2005 / Pollen of selected plant taxa in the air of Rzeszów 2001-2005). [in:] WeryszkoChmielewska E. (red.) Pyłek roślin w aeroplanktonie różnych regionów Polski. / Plant pollen in aeroplancton of different regions of Poland. Wyd. Wydz. Farmaceutyczny AM, Lublin: 93-103.

Kasprzyk I., Uruska A., Szczepanek K., Latałowa M., Gawel J., Harmata K., Myszkowska D., Stach A., Stępalska D., 2004. Regional differentiation in the dynamics of the pollen seasons of Alnus, Corylus and Fraxinus in Poland (preliminary results). Aerobiologia, 20: 141-151.

Kaszewski B. M, Czerniawski M., Mucha B., 2002. Warunki klimatyczne Roztocza. / Climate conditions of the Roztocze. [in:] Buraczyński J. (red.) Roztocze. Środowisko przyrodnicze. / Roztocze. Natural environment. Wyd. Lubelskie, Lublin: 208-220.

Matuszkiewicz W., 2001. Przewodnik do oznaczania zbiorowisk roślinnych Polski. PWN, Warszawa.

Pidek I. A., 2004. Preliminary results of pollen trapping in the region of the Roztocze National Park (SE Poland). Ann. UMCS, sect. B, 49, 9, Lublin: 143-159.

Pidek I. A., Weryszko-Chmielewska E., Piotrowska K., 2006. Comparison of pollen concentration of selected tree taxa in Lublin and in the Roztocze region (SE Poland) - the results of three monitoring methods. Acta Agrobot., 59, 1: 355-364.

Poska A., Pidek I. A., 2007. Estimating spatial scale of pollen dispersal in the semi-cultural landscape of the Roztocze region (SE Poland). [In:] Volume of Abstracts, Pollen Monitoring Programme, 6th International Meeting,3-9 June, 2007, Jurmala, Latvia: 69-73. 
Rodriguez-Rajo F. J., Dopazo A., Jato V., 2004. Environmental factors affecting the start of pollen season and concentrations of airborne pollen in two localities of Galicia (NW Spain). Ann Agric Environ. Med. 11: 35-44.

Rodriguez-Rajo F.J., Valencia-Barrera R.M., Vega-Maray A. M., Suarez F. J., Fernandez-Gonzalez D., Jato V., 2006. Prediction of airborne Alnus pollen concentration by using ARIMA models. Ann Agric Environ. Med. 13: 25-32.

Smith M., Emberlin J., Stach A., Czarnecka-Operacz M., Jenerowicz D., Silny W., 2007. Regional importance of Alnus pollen as an aeroalergen: a comparative study of Alnus pollen counts from Worcester (UK) and Poznań (Poland). Ann Agric Environ. Med. 14: 123-128.

Stockmarr J., 1971. Tablets with spores used in absolute pollen analysis. Pollen et Spores, 13: 615-621.

Sugita S., Gaillard M.-J., Broström A., 1999. Landscape openness and pollen records: a simulation approach. The Holocene, 9, 4: 409-421.

Suszka B., 1980. Rozmnażanie generatywne (Generative propagation). [w:] Białobok S. (red.). Olsze. / Alder (Alnus Mill.). Nasze drzewa leśne, 8. PWN, Warszawa-Poznań: 99-144.

Szczepanek K., 2006. Pyłek wybranych taksonów roślin w powietrzu Krakowa, 1993-1997 (metoda grawimetryczna). / Pollen of selected plant taxa in the air of Kraków, 19931997 (gravimetric method). [in:] Weryszko-Chmielewska E. (red.) Pyłek roślin w aeroplanktonie różnych regionów Polski. / Plant pollen in aeroplancton of different regions of Poland. Wyd. Wydz. Farmaceutyczny AM, Lublin: $13-20$

Szczepanek K., Tobolski K., Nalepka D., 2004. Alnus Mill. - Alder. [In:] Ralska-Jasiewiczowa M., Latałowa M., Wasylikowa K., Tobolski K., Madeyska E., Wright H. E. Jr. \& Turner Ch. (eds.), Late Glacial and Holocene history of vegetation in Poland based on isopollen maps. W. Szafer Institute of Botany, Polish Academy of Sciences, Kraków: 47-55.

Tauber H., 1974. A statistic non-overload pollen collector. New Phytologist, 73: 359-369.

Weryszko-Chmielewska E., Piotrowska K., 2004. Airborne pollen calendar of Lublin, Poland. Ann. Agric. Environ. Med. 11: 91-97.
Weryszko-Chmielewska E., Piotrowska K., 2006. Pyłek wybranych taksonów roślin w powietrzu Lublina w latach 2001-2005. / Pollen of selected plant taxa in the air of Lublin, years 2001-2005). [in:] Weryszko-Chmielewska E. (red.) Pyłek roślin w aeroplanktonie różnych regionów Polski. / Plant pollen in aeroplankton of different regions of Poland. Wyd. Wydz. Farmaceutyczny AM, Lublin: 105-115.

Zając A., Zając M. (eds.) 2001. Distribution Atlas of Vascular Plants in Poland. Pracownia Chorologii Komputerowej Instytutu Botaniki Uniwersytetu Jagiellońskiego, Kraków.

\section{Dziewięcioletnie pomiary opadu pyłku Alnus w rejonie Roztocza (Polska SE) na tle danych dotyczących roślinności}

\section{Streszczenie}

Depozycję pyłku olszy mierzono za pomoca dziewięciu zmodyfikowanych pułapek Taubera umieszczonych na poziomie gruntu w zróżnicowanych zbiorowiskach roślinnych zgodnie $\mathrm{z}$ regułami stosowanymi przez Pollen Monitoring Programme (http://pmp.oulu.fi). Aktualna seria danych obejmuje lata 1998-2006. Badany obszar zlokalizowany jest na Roztoczu Środkowym w okolicach wsi Guciów w strefie ochronnej Roztoczańskiego Parku Narodowego. Podczas dziewięciu lat prowadzenia monitoringu odnotowano duże różnice w wartościach depozycji pyłku Alnus w poszczególnych latach. Wśród nich zaobserwowano lata o bardzo wysokim wskaźniku depozycji (1998, 2001, 2003, 2006), co związane jest ze zwiększoną produkcją pyłku Alnus. Zjawisko to odzwierciedla się zwykle na wielu stanowiskach, ale związek depozycji pyłku z udziałem olszy w składzie roślinności wydaje się raczej słaby. Średnia roczna wartość rocznej depozycji pyłku Alnus obliczona dla całego regionu wynosi około 1370 ziarn $\times \mathrm{cm}^{-2}$. Na stanowiskach znajdujących się w otwartym krajobrazie wartości pollen influx wahały się w analizowanym okresie od 442 (w 2005 roku) do 6894 (w 1998 roku). Wydaje się, że inne czynniki niż procentowy udział olszy w roślinności kontrolują depozycję pyłku Alnus. W przyszłych badaniach należałoby wziąć pod uwage wpływ dalekiego transportu pyłku oraz czynniki meteorologiczne takie jak m.in. prędkość i kierunek wiatru. 